\title{
Miranda
}

Revue pluridisciplinaire du monde anglophone /

Multidisciplinary peer-reviewed journal on the English-

speaking world

13 | 2016

Thomas Spence and his Legacy: Bicentennial

Perspectives

\section{Annie Ramel, The Madder Stain: A Psychoanalytic Reading of Thomas Hardy}

\section{Laurence Estanove}

\section{OpenEdition}

\section{Journals}

\section{Electronic version}

URL: http://journals.openedition.org/miranda/9342

DOI: $10.4000 /$ miranda.9342

ISSN: 2108-6559

\section{Publisher}

Université Toulouse - Jean Jaurès

Electronic reference

Laurence Estanove, "Annie Ramel, The Madder Stain: A Psychoanalytic Reading of Thomas Hardy", Miranda [Online], 13 | 2016, Online since 25 November 2016, connection on 16 February 2021. URL: http://journals.openedition.org/miranda/9342 ; DOI: https://doi.org/10.4000/miranda.9342

This text was automatically generated on 16 February 2021

\section{(c) (i) (9)}

Miranda is licensed under a Creative Commons Attribution-NonCommercial-NoDerivatives 4.0 International License. 


\title{
Annie Ramel, The Madder Stain: A Psychoanalytic Reading of Thomas Hardy
}

\author{
Laurence Estanove
}

\section{REFERENCES}

Annie Ramel, The Madder Stain: A Psychoanalytic Reading of Thomas Hardy (Leiden \& Boston: Brill Rodopi, 2015), 55 euros, 190 p, ISBN 9789004293403

1 Few approaches in literary analysis can be as divisive and garner as many passionate reactions as psychoanalytical readings. Published as volume 21 of the Contemporary Psychoanalytic Studies book series, Annie Ramel's The Madder Stain is refreshingly bold in that it unapologetically embraces the Lacanian perspective to examine Thomas Hardy's work with a unique slant. Hardy has been seen by many scholars as having produced fiction that somehow anticipated Freud's theories; it is therefore not so surprising that his writings should lend themselves well to the perspective chosen here by the author. Indeed, for one who knows the importance in Hardy's work of death, desire and sexuality, lineage and origins, the echoes to be found in psychoanalytical concepts such as the Lacanian Real or the Object-Gaze seem barely refutable. "[A]s Lacan reminded us," Ramel notes, "the artist always precedes the psychoanalyst" (50).

2 However, what also remains undeniable is how difficult the access to Lacan's theory and language are to most readers and critics. Ramel's work is particularly interesting in that respect, as it is both a book about Hardy and about the relevance of psychoanalysis to literature: it offers an excellent way to get acquainted with Lacanian concepts and understand how they might indeed be perfectly relevant to literary analysis, however obscure the theory may appear, and whatever understandable reservations one may have. 
Ramel focuses exclusively on Hardy's fiction, poetry being but barely mentioned - not that there isn't enough to say with the bulk of Hardy's fiction dealt with by the author, far from it: Ramel's analyses cover seven novels and a few short stories. Quite expectedly, the emphasis of her study is often on character analysis and on the tragic dimension of Hardy's plots and figures, testifying to an accurate knowledge of Hardy criticism up the more recent key publications such as Rosemarie Morgan's Ashgate Research Companion and Jane Thomas's Thomas Hardy and Desire. Ramel also offers an impressive coverage of Lacan's writings (both in the original French text and in English translations) as well as essential criticism, Žižek featuring quite prominently there. Yet she manages to translate complex psychoanalytical concepts into an accessible adequate language, while remaining uncompromisingly Lacanian. The awareness that her readers might not be familiar with Lacan is obvious throughout the book: Ramel is careful to provide detailed justification for her choice of terms and concepts, and though some may find the important amount of footnotes a hindrance, for the most part the book manages to strike a good balance between what explanations the reader might be expected to require or not.

4 However steeped in Lacanian theory Ramel's book may be, it never strays from the Hardyan text which is undeniably its prime concern, offering thoughtful elaborate examinations of its smallest details. Rarely do scholars focus on such minutiae of the text as the symbolic linguistic patterns that Ramel points to, e.g. the relevance of names, sounds and syllables with their punctum effect: one may mention in particular the study of "Ur" encapsulating the power of origins in Tess and other novels (155-157), or the "ring" as key word and motif signalling a tragic void that cannot be breached $(31-35,168)$. The psychoanalytical perspective allows Ramel both to extract such details from the recesses of the text and to reveal their full significance to a wider perspective, one that extends beyond the limits of a sole novel or of Hardy's work. This is, for instance, how she comes to link the sexual jouissance to an "Other" jouissance attached to the very nature of fiction, that of reading and writing (7). She also argues that the "feminine pursuit" is akin to the "artist's quest" (64-68), as the latter encapsulates both the authorial voice, with its "phallic temptation of order, clarity and univocity" and "the textual voice", "the voice of equivocation and ambivalence, which undermines the phallic construction of meaning" (67).

5 Ramel's study is also particularly enlightening in its reassessment of famous scenes from Hardy's work, such as the cliff scene in A Pair of Blue Eyes (19-21) or the moment in Tess describing the young woman's sensations as she crosses the garden at Talbothays. There, Ramel sees in Tess's experience the "oceanic feeling" described by Freud in The Future of an Illusion (57), arguing that Tess's enjoyment is more than sexual arousal or phallic enjoyment precisely because, as made clear by Lacan, feminine jouissance, "the Other, unspeakable jouissance", is "Beyondsex" (58), "involv[ing] the soul" (59).

6 Being indisputably the most known and studied of Hardy's novels, Tess offers an ideal entry point for Ramel, also quite expectedly so given the central place such questions as death and desire occupy in the novel. Though the motif of the stain is what Ramel starts from - "the sheer, absolute, insoluble mystery of the 'madder stain' as a point of contact with the unspeakable Real, the Lacanian Real" (3) - her study does not limit itself to the examination of sexuality. Roland Barthes's notion of the punctum is key to her reassessment of the red spot from a psychoanalytical perspective because of what she sees, very convincingly, as the vocal quality of the stain. 
7 Similarly, her take on the Hardyan tragic is made particularly interesting by her use of the notion of a surplus object "that jams the system" (15). As the accident of Tess's horse Prince testifies, she argues, it is the presence of an object blocking the way, rather than a threatening hole, that causes tragedy: "all is blocked in the tragic world because no such gap exists, because a surplus object occupies the place that should be left vacant" (15-16). Remaining on the brink of the hollow left by that missing object is what keeps from falling into tragedy, and Ramel thus aptly examines the recurrence of motifs of avoidance and decentring in Far from the Madding Crowd: "Comedy deals with the detours of human life, tragedy with the straight line [...]. That is why it is essential for the stream vomited by the gargoyle to be directed sideways. The comic resolution of the novel is due to Boldwood's man, Samway, deviating the second gunshot to the beam across the ceiling" (83).

8 Also particularly enlightening is Ramel's convocation of painters such as Holbein and Munch, the former allowing for fascinating analyses of anamorphosis in The Return of the Native and Far from the Madding Crowd (84-97, 110-118), showing the "split" or "lack of reciprocity" between gaze and eye (89). As to Munch, his famous Scream appropriately serves Ramel's examination of muted voices and muffled sounds in Hardy's plots and writing, as she explains that both Munch's painting and Caravaggio's Testa di Medusa "make the failure of voice visible" (138).

9 The book's overall line of argument thus offers compelling dynamics that connect the visual ("object-gaze") to the vocal ("object-voice") in order to expand the reader's understanding of the Hardyan aesthetics and poetics. To Ramel, what is essential to Hardy's aesthetics is the presence of an object "causing a failure in representation" (128). Similarly, the "radical enigma" of the "madder stain" constitutes in Ramel's view the mark of Hardy's distinctive poetics, his signature or "voiceprint" (168).

For a book dealing with such prolific writers as Hardy and Lacan, Annie Ramel's study shows surprising concision, which seems particularly appropriate to difficult and controversial approaches, and as such it gives the reader unfamiliar with - and even wary of - the psychoanalytical perspective an extremely useful insight as well as a reference study to return to. While non-Lacanian readers may not adhere to all readings and analyses presented in the book, one should remember that there is a lot to learn from looking at an author so known and studied as Hardy in an unfamiliar light. If only to experience that sense of the uncanny which is perhaps the best way to approach "the margin of the unexpressed" that Woolf had famously detected in Hardy's writing.

\section{INDEX}

Keywords: psychoanalysis, jouissance, gaze, voice, sexuality, death, origins Mots-clés: psychanalyse, jouissance, regard, voix, sexualité, mort, origines 
AUTHORS

LAURENCE ESTANOVE

PRAG

Université Paris Descartes

laurence.estanove@gmail.com 